\title{
LANGUAGE LEARNing IN THE TIME OF COVID-19: ELT STUdents' Narrated Experiences IN GUIDED REFLECTIVE JOURNALS
}

\author{
APRendizaje de Lenguas En TIEMPOS DE COVID-19: EXPERIENCIAS DE DOCENTES \\ DE INGLÉS EN FORMACIÓN CONSIGNADOS EN DIARIOS REFLEXIVOS
}

L'APPRENTISSAgE DES LANGUES AU TEMPS DU COVID-19: DES EXPERIENCES DES ENSEIGNANTS EN FORMATION CONSIGNÉES DANS DES JOURNAUX DE RÉFLEXION

\author{
Amanda K. Wilson \\ Professor, Departmento de Lenguas, \\ Universidad de Guanajuato, \\ Guanajuato, México. \\ wilsonakay@gmail.com \\ https://orcid. \\ org/0000-0003-3897-5631

\section{Martha Lengeling} \\ Full Professor, Departmento de \\ Lenguas, Universidad de Guanajuato, \\ Guanajuato, México. \\ lengeling@hotmail.com \\ https://orcid. \\ org/0000-0002-2570-5002
}

\begin{abstract}
This article presents the results of a qualitative study of the lived experiences and emotional responses regarding language learning of 29 students in a bachelor's degree in English language teaching (ELT) offered at a public university in central Mexico. The study was grounded in sociocultural theory and was carried out at a time when the students' classes changed overnight to online learning due to the worldwide covid-19 pandemic. In this program, students learn a foreign language within a theoretical framework of second language acquisition (SLA) and document their language learning experience (LLE) through reflective journals. One month into the new online modality, they were asked to write in their journals about a historical artifact that would represent their experience during the pandemic for a historian 100 years in the future. A constant comparative method of analysis of their narrated stories reveals the challenges faced and ensuing emotions: from overwhelming anxiety to youthful optimism. These results provide an appreciation of students' complex emotions regarding their language learning process while in the midst of a worldwide pandemic and highlight the importance of creating activities that promote reflection.
\end{abstract}

Keywords: COVID-19; ELT; emotions; guided journals; narrative inquiry; reflective journals; teacher education.

\section{RESUMEN}

En este artículo, presentamos los resultados de un estudio cualitativo fundamentado en la teoría sociocultural de las experiencias vividas de 29 estudiantes en clases de lengua extranjera como parte de un programa de Licenciatura en la Enseñanza del Inglés en una universidad pública del centro de México. El estudio se basó en

Received: 2021-02-26 / Accepted: 2021-06-30 / Published: 2021-09-11

https://doi.org/10.17533/udea.ikala.v26n3a06

Special issue on The Role of Technology in Language Teaching and Learning amid the Crisis Generated by the COVID-19 Pandemic. Editors: Marta González-Lloret, University of Hawai'i at Mānoa, UsA; Laia Canals, Universitat Oberta de Catalunya, Spain; Jorge Pineda, Universidad de Antioquia, Colombia.

(C) 2021 Universidad de Antioquia. This is an open access article distributed under the terms of the Creative Commons License BY-NC-SA 4.0 International. 
teorías socioculturales y se llevó a cabo cuando sus aulas cambiaron al aprendizaje en línea debido a la pandemia mundial de covid-19. En este programa, los estudiantes aprenden una lengua extranjera dentro de un marco teórico de adquisición de idiomas y documentan su experiencia de aprendizaje de idiomas a través de diarios reflexivos. Un mes después de la nueva modalidad en línea, se pidió a los estudiantes que escribieran en sus diarios sobre un artefacto histórico que representaría su experiencia durante la pandemia para un historiador de 100 años en el futuro. Utilizando un método comparativo constante, las historias narradas en sus diarios guiados iluminan los desafíos enfrentados y las emociones resultantes, revelando desde un optimismo juvenil a una ansiedad abrumadora. El estudio tiene implicaciones para comprender las respuestas emocionales de los estudiantes en cuanto a su proceso de aprendizaje de lenguas en medio de una pandemia, y resaltan la importancia de crear actividades que promuevan la reflexión.

Palabras claves: COVID-19; diarios guiados; ILE; emociones; formación docente; indagación narrativa; diarios de reflexión.

\section{Résumé}

Cet article présente les résultats d'une recherche qualitative basée sur les expériences vécues de 29 étudiants en cours de langues étrangères dans le cadre d'un programme License en ELT, dans une université publique du centre du Mexique. Fondée sur la théorie socioculturelle, l'étude a été menée lors du changement de la modalité présentielle à virtuelle pendant la pandémie mondiale de CoviD-19. Dans ce BA, les étudiants apprennent une langue étrangère dans un cadre théorique d'acquisition de langue seconde et rapportent leur expérience d'apprentissage des langues à travers des journaux de réflexion. Un mois après le début du changement à la modalité virtuelle, on a demandé aux étudiants d'y décrire un artefact à un historien vivant 100 ans dans le futur qui représenterait leur expérience vécue pendant la pandémie. En utilisant une méthode comparative constante, les histoires racontées dans leurs journaux de réflexion par les enseignants en formation éclairent les défis rencontrés et les émotions qui en résultent, révélant tant un optimisme juvénile qu'une anxiété écrasante. Cette étude permet de comprendre les complexes émotions des étudiants à propos de leur processuss d'apprentissage au milieu d'une pandémie et surligne l'importance de créer des activités qui favorisent la réflexion.

Mots-clés: COVID-19; ALE; émotions; enquête narrative; formation des enseignants; revues de réflexion; revues guidées. 


\section{Introduction}

On March 15, 2020, at 12:52 a.m., life changed for teachers and students in our public university in central Mexico when an email from the university announced the suspension of classes due to the worldwide coronavirus pandemic. When COVID-19 hit, the participants in this study were enrolled in a bachelor's degree (BA) in English language teaching (ELT). The BA includes a language learning experience (LLE) in which students study a foreign language ( $\mathrm{FL}$ ) other than English within a theoretical framework of second language acquisition (SLA) and complete individual action research (AR) projects about their language learning process. In addition to taking and passing an FL class, the students keep journals detailing their AR projects and reflecting on their experience through guided prompts. As our university community ventured into the new reality caused by the pandemic, face-to-face BA class meetings transformed into online synchronous classes, while students' FL classes either did the same, moved to asynchronous platforms, or were cancelled entirely. In this article, we analyze the data from the students' reflective journals to explore their emotions while learning a language during COVID-19.

Learning is the interconnection of emotion and cognition, as described by Vygotsky's (1994) use of the Russian term perezhivanie. The role of cognition in learning is the subject of much research while emotions have been considered to a lesser degree. Where research has explored emotions in learning, the traditional focus has largely been within a language classroom or resulting from the use of a second language (12) outside of the classroom (Arnold, 2011; Horwitz, 2016; Richards, 2015). The worldwide pandemic has been a difficult time for learners, but the very immensity of this experience provides a unique opportunity to study learners' emotions in a more "general" (MacIntyre \& Gardner, 1994) sense. We now see research examining emotional responses to COVID-19 (Aristovnik et al., 2020; Karalis \& Raikou, 2020) and studying the facilitation of space for cognitive development (Chakma et al., 2021; Pasaribu \& Dewi, 2021). Little has been explored, however, regarding the use of reflective techniques within a facilitated space to explore emotions when a social phenomenon such as COVID-19 affects learning.

For our study, students were given a guided journal prompt about their experience in the time of COVID-19 from an imagined perspective in the future. Written during the transition from inperson to online classrooms as our world was being turned upside down because of wholesale lockdown and overwhelming uncertainty, these guided journal entries offer a window into the students' lives and provide insight into their emotions during COviD-19. The data is viewed through a Vygotskian lens to help us understand student emotions during a new social phenomenon.

\section{Theoretical Framework}

For this research, we recognize that while social phenomena may trigger different individual emotional responses, these responses nonetheless reveal information relevant to understanding the role of emotions in language learning more generally. The theory that supports this research is therefore informed by three areas: sociocultural theory, embedded LLE programs, and emotions in language learning.

\section{Sociocultural Theory}

The sociocultural stance adopted here is that we, as individuals, are shaped by our lived experiences and those experiences are therefore key in our quest to understand how COVID-19 has affected language learners. This sociocultural perspective is grounded in a view that "it is through others that we develop into ourselves" (Vygotsky, 1981, p. 161). Individuals are formed by both the "personal" and the "contextual," and both aspects are relevant to this investigation.

The context examined here is the language learning experience during a worldwide pandemic and the resulting move to online or remote learning. Sociocultural theory incorporates the Russian

\section{3}


term perezhivanie (Vygotsky, 1994), meaning that different people may react to the same environment in different ways. Success in learning a new language is the result of an intricate process recognized to be a consequence of both the individuality of students as well as their environments, a unity of cognition and emotion. The complexity created by this circle of "personal" and "contextual" influences arises because our experiences within any particular context are interpreted through and by our individual "self," what Golombek and Doran (2014) identify as a "prism of perezhivanie" (p. 104). The individual prism is fundamental in understanding how remote learning and the coronavirus pandemic have affected individual language learners. In this study, we view the individual experience of our participants within a shared social phenomenon by examining their personal responses and analyzing the common themes that emerge from that shared experience. These themes then reveal a bigger picture which helps shed light on language learning in this context.

\section{Embedded LLE Programs}

In teaching programs throughout the world, teacher cognition and how that translates into teaching practice is recognized as an important area of study. Personal experience is an essential component in cognitive development for teachers, as Lortie (2002) recognized in describing the apprenticeship of observation. This apprenticeship arises from the experience teachers have before entering the profession, as students who have spent perhaps thousands of hours in a classroom observing their own teachers. For English teachers in countries such as Mexico, where English is not the native language, future teachers generally learn the language they will eventually teach as students in an English-language classroom. Through this experience, they develop their own perceptions about how to teach a language, for better or worse.

The idea behind Lortie's (2002) theory is extended in a more formalized manner by embedding an LLE within a BA in ELT (Ellis, 2004; Flowerdew, 1998; Forman, 2015). Learning another language as an explicit part of ELT education provides students with a perspective that goes beyond that described by Lortie's apprenticeship of observation. LLE students' experiences are also informed by the theory they are learning as part of their studies: theory about language teaching and SLA theory. Thus, students may experience the theory they are learning in an ELT program as it is put into practice in a language classroom.

Embedded LLE programs can enhance cognitive development, but as Ellis (2004) explains, "this experience can only be significant if it becomes available to teachers through a process of reflection" (p. 92). Reflection based on personal experience and grounded in theory results in a richer understanding, allowing students to "gain insights into the language learning process by reflecting upon their LLE and relating it to the SLA research literature" (Forman, 2015, p. 2). The goal is for ELT students to recognize for themselves the complexity of learning a new language and gain an understanding of "how languages differ at the levels of pronunciation, lexical meaning, syntax, pragmatics and cultural norms" (Ellis, 2004, p. 96). An awareness of language learning brought about by personal experience within a purposeful ELT classroom context creates an appreciation that goes beyond received knowledge in a traditional classroom. It allows students to experience the emotional aspects of language learning and provides an opportunity to recognize the role emotions may play for their own future English language students.

In defining language learning awareness, Ellis (2012) notes the importance of this lesson for ELT students: "Language learning awareness is the understanding of and empathy with the challenges faced by learners of an additional language, and I would argue that it is only achievable through direct experience and reflection upon that experience" (p. 15). This direct experience allows students to reflect upon and explore the realm of emotions inherent in language learning. 


\section{Emotions in Language Learning}

Language learning has been described as the result of "what goes on inside people... [and] [w] hat goes on between people" (Arnold, 2009, p. 145), with both describing the emotional side of learning. Scovel (2001) writes, "Emotion is the single most influential" (p. 125) of the components of SLA theory, although perhaps the least understood. Emotions in learning are often thought to be difficult to study because of their complexity, and because emotions are both highly individual and sometimes hidden. Nonetheless, the need to understand the influence of emotions in learning is creating a "growing shift in the field toward the treatment of emotion as a distinct topic of scholarly inquiry in its own right" (Prior, 2016, p. 3). Recognition of the importance of emotions more specifically in language learning is also increasing (Richards, 2015; Song, 2016; Prior, 2016), including in Mexico (Mendez Lopez, 2020; Lengeling, 2010).

Hargreaves (1998) provides the source of the word emotion: "The Latin origin of emotion is emovere: to move out or stir up. When people are emotional, they are moved by their feelings" (p. 835). This response to feelings is socially constructed but takes place internally, which Zembylas (2003) describes as "a psychological phenomenon that is 'located' in the individual" (p. 216). The complexity of this cognitive process is recognized by Carlyle and Woods' (2002) explanation that emotions "link...feeling, thinking, and actions" (p. xiii). We use the term 'emotion' here but recognize that in the literature, affect is also used as "the more technical term" (Scovel, 2001, p. 119). Arnold (2009) writes, "The term affect refers essentially to the area of emotions, feelings, beliefs, moods and attitudes, which greatly influences our behavior" (p. 145). It is the behavioral influence, specifically on cognition, that is relevant for language learning research.

Emotions occur in all contexts (Zembylas, 2003) and produce a wide range of responses (Arnold, 2009; Prior, 2016). Within that range, prior research has primarily focused on aspects such as motivation and anxiety (Scovel, 2001). Dörnyei and Ushioda (2011) conclude, "Perhaps the only thing about motivation most researchers would agree on is that it, by definition, concerns the direction and magnitude of human behaviour" (p. 4), meaning the why, how long, and how hard people will do something. Different types of motivation include integrative (Masgoret \& Gardner, 2003), extrinsic and intrinsic (Noels, 2001), and future self-image (Dörnyei \& Chen, 2013). Motivation is one of the widest areas of research about emotions in language learning, followed by anxiety (Horwitz, 2016; MacIntyre \& Gardner, 1994).

Scovel (2001) describes anxiety as "a vague sense of unease" (p. 127), while Richards (2015) refers to worry and stress in identifying anxiety as "[o]ne of the most important affective factors" (p. 154). Prior research has generally focused on emotions within a classroom setting or resulting from the use of L2 outside of the classroom (Arnold, 2011; Horwitz, 2016; Richards, 2015).

As a result of Covid-19, researchers are recognizing the opportunity to examine student emotions during the pandemic. These studies generally apply questionnaires about student emotions using closed questions with a Likert scale, along with a few open-ended questions. By their nature, they do not reach an in-depth reflection relating emotions and learning to the individual learner. For example, Aristovnik et al. (2020) report the results of a large-scale study at the beginning of the pandemic in which data was collected from university students in 62 countries using a web-based survey and Likert scale for primarily closed-ended questions about what student life looked like during the pandemic. Their study includes statistical information about student emotions such as boredom, anxiety, and frustration, but it does not address the important role of reflection as it relates to emotions in learning.

More closely aligned with our study is an investigation into student emotions at a university 
in Greece at the start of the pandemic by Karalis and Raikou (2020). Their participants were also student teachers, although they were not simultaneously studying a language. Data was collected using an online questionnaire and included six closed-ended questions using a Likert scale and seven open-ended questions. The authors' statistical analysis of the participants' emotional response to online learning produced categories such as relief, joy, curiosity, pleasure, enthusiasm, and disappointment. From this, they conclude that there is "good reason for the renewal and development of teaching and learning in the university context” (p. 492).

Other research, such as that reported by Pasaribu and Dewi (2021), includes student reflection. In this study, EFL students at a private university in Indonesia were asked to submit written reflections describing such things as how COvID-19 changed their lives, what and how they learned through online classes, how they felt about online classes, and what they did to prepare for final evaluation in their classes (p. 406). Their analysis of the data using appraisal theory to identify and quantify student emotions found that "online learning has offered the students...opportunities to exercise learner autonomy and enhance social engagement" (p. 420).

Finally, as graduate students in Australia during Covid-19, Chakma et al. (2021) created an online study group as a "facilitated space" (p. 37). They each wrote and shared "a retrospective narrative to reflect on what they had expected, thought or did before, during and after" (p.44) their online study group sessions. In reporting on this experience, they identify themes which show the online space provided a better understanding of the process of writing, a self-awareness of their learning styles, and support in completing their graduate theses.

Coupling emotions with a worldwide pandemic provides opportunities to understand how students make sense of their LLE. Specifically, in this article we look at social construction of emotions through student reflection from an imagined perspective during the time of COVID-19, and the research method selected to help us see and understand those emotions is described next.

\section{Method}

Using a qualitative approach, this study views our students' narrated stories through a Vygotskian lens. The purpose of qualitative studies is to understand human experience by "attempting to make sense of, or interpret, phenomena in terms of the meanings people bring to them" (Denzin \& Lincoln, 2005, p. 3). By recognizing the complexities and uncertainties involved in individual experiences, a qualitative paradigm allows us to “illuminate' the life circumstances of individuals and communities" (Squire et al., 2014, p. 74), thereby leading to a deeper understanding of the human experience in response to social phenomena.

Narrative inquiry as a methodology is well suited to understanding the participants' LLE during Covid-19. Barkhuizen and Wette (2008) describe stories of experience as "the core of any narrative research activity" (p. 373), and it is therefore through our students' stories that we seek to understand their experiences. The "living and telling, and re-living and re-telling" (Clandinin et al., 2013, p. xv) of their stories allows us to examine their emotions while learning a language during a worldwide pandemic.

Although our participants may have had shared learning experiences, they lived those experiences individually. As a methodology for exploring their individual experiences, narrative inquiry is therefore coherent with the Vygotskian perspective taken here as it recognizes the importance of the individual within a specific context and allows for the interplay of those distinctive perspectives.

The stories presented here come from guided reflective journals, as described in more detail below. Farrell (2013) explains that reflecting "means that teachers subject their own beliefs, 
assumptions, and values about the teaching and learning to a critical analysis" (p. 33), but further clarifies that structured reflection is necessary to be effective. Such structure allows thinking to take form. According to Golombek and Klager (2019), "As thinking is externalised in utterances, in speaking or writing, it becomes an object of reflection, questioning, critique, rejection, elaboration and possibly transformation by ourselves or in collaboration with others" (p. 41). Guided journals are one means of providing structure to externalize our thinking. When guided to reflect on a specific social event, these narratives can reveal "how personal lives traverse social change" (Squire et al., 2013, p. 4). As described by Barkhuizen, the participants' narratives help us make "connections to the macro-context" (Wilson, 2017, pp. 5-6) in order to see how they experience a social phenomenon such as Covid-19. With that goal in place, we began the process of collecting our students' experiences within a narrative framework. Next, we introduce the participants within their academic context.

\section{Context and Participants}

The context of this study is within a four-year $\mathrm{BA}$ in ELT program at a public university in central Mexico. The BA offers a series of courses over three semesters in which students enroll at a language school of their choice. Their individual LLE is the focus of an AR project conducted by the student within an SLA theoretical framework (Brown, 2014; Scovel, 2001) in coordination with their BA class. The participants in this study were in the first and third semesters of these courses when the university announced the suspension of face-to-face classes and the subsequent move to online learning due to COVID-19.

To be accepted into the BA, all students must have an academic proficiency in both Spanish and English, so students have already learned at least a second language before beginning their BA studies. During the three LLE classes, students complete individual AR projects based on their own FL learning experience. AR encourages reflection and adjustments to teaching and learning through "a spiral or cycle of movements between action and research" (Burns, 2009, p. 290). It is something that some teachers do instinctively, but which can lead to continued professional growth when done purposefully and consciously. The stages within a cycle involve identifying a research issue, developing a plan of action to address the issue, implementing the plan, gathering data by observing the effects of the plan, reflecting on the data, modifying the plan, and then starting a new cycle until the researcher achieves their goal related to the identified research issue (McNiff \& Whitehead, 2002). The objective for our BA students is for them to have the experience of learning an FL from the perspective of an ELT student, to reflect on their own learning process based on SLA theory, and thereby gain a better appreciation of the complexities of language learning and teaching.

The BA program promotes a communicative language teaching (CLT) approach (Richards, 2015), and in the three LLE classes, CLT ideology is incorporated as a way of teaching by example. In the first semester, students have weekly classes with their BA teacher while also taking an FL class. They identify an AR question related to their own LLE and, throughout the semester, compile a portfolio including a reflective journal, FL class materials, and student-created didactic materials. In keeping with a CLT approach, classes are student-focused and experiential. Rather than learning through the use of language (Richards, 2015, p. 71), the BA students learn through their use of SLA theory. Students present assigned topics related to SLA (Scovel, 2001) as well as their individual AR projects. In the second and third semesters, students continue taking FL classes and attending the BA class, with ongoing presentations and group discussions. In addition to the reflective journal and other portfolio materials described above, in the second semester, students prepare academic papers specific to SLA theory related to their AR projects. Finally, during the third semester, students 
complete an academic paper reporting on their AR project and analyzing their FL learning experience. Reflective journals are an integral part of the three LLE classes. They contain students' data for their AR projects as well as a number of guided journal entries intended to promote student reflection.

In this study, 29 students participated: 21 were enrolled in the first semester and eight in the third semester. Of those, five are men and 24 are women, and their age range was 20 to 43 . All of the participants are fluent in English and Spanish, and most are Mexican nationals although two students grew up and went to school in the USA before moving to Mexico. While enrolled in the BA, 16 of the participants were already teaching English in a variety of contexts: public and private schools, urban and rural communities, and with different student levels and ages. These in-service teachers had teaching experience ranging from beginner to 12 years. The remaining 13 students were pre-service teachers who had not yet begun teaching. Although the students generally had a good grasp of technology prior to Covid-19, some relied on internet cafes or computers at the university as they did not have dependable access to the internet and computers in their homes.

As our university community ventured into the new reality caused by the global pandemic and teachers scrambled to adjust their semester plans and find resources for online learning, the students also struggled to secure computer and internet access that would allow them to finish the semester while locked down in their homes. Our BA class meetings transformed into online synchronous classes using Zoom, while students' FL classes either moved to similar synchronous platforms, various asynchronous platforms (e.g., email, Google classroom), or were cancelled entirely, depending on the language teachers' individual circumstances. Throughout this time, the students continued to keep their AR journals, and how those developed as a data collection tool for this study is discussed next.

\section{Data Collection and Analysis}

One month into the new modality, the students' reflective journals were recognized to be a valuable resource to help us all, students and teachers alike, make meaning of this unprecedented experience. An added journal entry assignment gave students a space to reflect on their lived experience:

\section{Consider a historical artifact that could represent your experience during this pandemic to a historian 100 years in the future. Artifacts are objects shaped by humans that are of historical interest. Examples inclu- de tools, pottery, metal objects, weapons, and items of personal adornments, such as jewelry or death masks. (modified from Strauss, 2020)}

This journal prompt gave students the opportunity to reflect on their experience from an imagined perspective removed from their current environment. It placed them in the future, as a survivor of the coronavirus pandemic, anonymously communicating with an unknown future historian. In addition, by asking students to describe a historical artifact, it triggered their imagination and creativity. Moon (2006) encourages reflective writing as a means of gaining a deeper reflection and more meaningful understanding "by standing back from an event" (p. 162). With this guided journal, students were allowed to stand back from their immediate reality in order to gain a deeper level of reflection. These guided journal entries developed in response to our new reality and now provide a window into students' experiences as their lives were changing due to the worldwide pandemic.

The journals were submitted electronically at the end of the semester as part of the BA class portfolios. Once the students provided written consent to participate in this investigation, pseudonyms were assigned to ensure their anonymity. Those pseudonyms are used to identify the data in the discussion below. The guided journal entries were compiled and reviewed using thematic analysis (Barkhuizen, 2019). Both authors first worked individually to identify particular themes. Then working 
together, they compared the emerging themes using a constant comparative method (Richards \& Hemphill, 2018) to identify similarities and differences in the journal entries. The data was scrutinized again to correlate the emerging themes with the data. This individual and joint review helps to avoid researcher bias and maintain principles of submission to the data and emergence of themes (Holliday, 2007). The data was then organized according to the themes for further analysis. The themes which emerged are (1) the challenges faced, technological and societal, and (2) a rollercoaster of emotions, highs and lows.

\section{Results}

The participants in this study are both FL learners and students in a BA in ELT program, which gives them an awareness of language learning based on their studied knowledge of theory. This perspective helped them unpack their lived experiential knowledge (Ellis, 2012) and offers a greater insight into their pandemic experiences. We begin by presenting data related to their challenges during the beginning stages of COVID-19.

\section{The Challenges Faced: Technological and Societal}

Language learning changed suddenly when inperson classes were suspended due to Covid-19, moving from in-person to online or remote classrooms. Students' efforts to find and use the technological tools needed to stay connected to their teachers and classmates present a common theme in the data. In their journals, students wrote about the internet, their computers, cellphones, internet platforms, and applications as their choices of historical artifacts representing their experiences. As one student, Pati, explained, "If there are no technological tools, the learning process is detained. To be honest, I have the possibility to have both the internet and a computer, but some students do not have the same opportunity." Although Pati had the necessary tools, she recognized that some classmates did not and were being left behind.
Students found they were completely dependent on the internet and their computers or cellphones. In explaining her choice of historical artifact, Ana wrote:

A cellphone allows us to be in contact with our teachers, classmates, and our co-workers from home...I believe that without cellphones we would not be able to do a lot of the stuff that we have to do to keep going with the semester or with our jobs.

Although cellphones may have been familiar technology, online classes presented other new challenges. Leo described his experience:

\section{This period of time has been based a lot on learning new stuff related to teaching and learning due to this period of covid-19. I have used a lot of platforms to develop my teaching and some apps to practice my learning... These platforms and their functionality must be developed and learned to use properly.}

To accompany this new use of familiar tools, students were challenged to learn new skills to continue their studies. Zoom was a common selection of one of these tools. Yolanda wrote, "I had to download an unknown app called Zoom... This app will go down in history for being known as the app that saved many communication connections around the world for many different purposes." Although the participants who chose Zoom as their historical artifact found that it made it possible for them to attend online classes, they also voiced connectivity issues as an obstacle. As Yolanda further described, "Sometimes we would freeze online" while Elena noted there were "problems with the internet connection and with the lack of social interaction." Technology allowed students to continue their studies, but it did not provide a complete substitution for their traditional classroom experience.

Even with the practical function of technology in online learning, students found ways to personalize their experience, as Samuel demonstrated in his journal entry:

The artifact that would be representative from this time would be a phone stand crafted by my brother during this pandemic. It is made of ceramic material... 
I even wrote the words "coronavirus edition" on it, so it is a very interesting artifact to be analyzed 100 years in the future.

Our students managed to integrate technology into their studies as well as their personal lives, making connection with school, friends, family, and the outside world possible, while still maintaining their individuality. The journal responses show how students faced challenges such as learning new technology while dealing with limited access to WiFi, computers, and cellphones to continue their education and work. The data also reveals the effect of technology on their identity needs. Although there is much research about student voices, a search for similar findings related to student identity and the use of technology for remote learning during COVID-19 indicates that this is an area which needs more study.

The participants' selection of artifacts demonstrates an ability and willingness to adapt to a new learning modality, to learn new skills necessary for the transition to online learning, and to change their way of thinking about learning. The data reveals a determination and resourcefulness in overcoming challenges during COVID-19, and a desire to maintain social contact along with individuality in an otherwise isolating situation. In the following section, we see how facing these difficulties also carried some strong emotional responses.

\section{A Roller-Coaster of Emotions: Highs and Lows}

When COVID-19 spread worldwide, our students reacted with an array of emotions depending on their foreign language class experience, personal lives, and individual contexts. The data reveals a roller-coaster of negative and positive emotions. Elena described feeling enthusiastic at first and how that then changed:

At first, Zoom was the new thing. Then, it was the phase in which we were enthusiastic about it, as we were working from home in our pajamas. It was innovative and it was even stimulating to use this platform to work or to take classes. Then, we discovered its disadvantages.

Students had to isolate at home when in-person classes were suspended. Elena embraced a new mode of learning from home, but her positive emotions at the beginning changed as she experienced emotional lows. Anita wrote about a set of flashcards she created for her FL class using emojis to represent a vocabulary of emotions:

\section{Although I was feeling happy for being with my fa- mily, I was also sad because of not going to class and other personal situations. I was angry because I could not manage my time. I was relaxed because I was home with my loved ones. These flashcards hold and represent my feelings during this pandemic.}

The data demonstrates her wide range of emotions during COVID-19, the highs and lows. Regarding her emotional responses, Edith similarly described how the pandemic affected her life: "This pandemic changes our lives and routines. We become more conscious about the smallest things that we do. It is hard to celebrate birthdays without hugs from the people you love." Edith described how COVID-19 caused people to "become prisoners," which she feared affected their mental health. In describing an artifact to represent her experience, she wrote:

If I have to keep an object to explain this situation it should be a facemask because it represents the protection but at the same time the silence, there are no people talking in the coffee shops, streets, schools, etc. Everything is quiet. It does not matter how many times you are screaming, telling someone to stop this situation, nobody seems to hear. Human beings are dying, and we still are in silence, far away from the people we love.

Social activities that were once part of her life are now different, making her feel imprisoned. Edith described being both protected and silenced at the same time, and the feeling that no one was listening.

María similarly wrote about her emotional response to facemasks, demonstrating how her emotions evolved: 
The few times I have been out I feel a mixture of emotions. For example, fear of not knowing what will happen next; amazement to see so many people wearing facemasks and not leaving their normal activities. And the most curious: I feel like I am in one of those zombie or epidemic movies. Never in my life did I imagine that we would live in a situation like this, but here we are and an artifact as simple as a mask has changed my life and that of other people.

While reflecting about the changes in her life outside of the online classroom, the facemask represented a needed change to continue her life, leaving her with the feeling that she was in a horror movie. This artifact represented her experience, and from the data, we recognize that anxiety was high on the list of emotions. Her choice of artifact shows how out-of-class emotions during COVID-19 impacted learning.

Students described their emotional struggles when dealing with issues in their home lives, their studies, and other contexts, and how they responded to those challenges. Juanita expressed her feelings about moving from her small hometown back to the university over $100 \mathrm{~km}$ away, leaving her family behind:

A modem because I had to come back to Guanajuato to finish my classes. A modem because it represents the inequality that exists in the world. Because some students are struggling with their classes because they do not have internet, and they do not have the money to rent internet because they lost their jobs and it is more important to have food on their table. My mom lost her job, my cousins, uncles, and aunts. I know how my little cousins that are studying secondary are struggling with their homework.

Here, her use of the word "inequality" indicates the unfairness she felt because she had to leave her family, because of her struggles with the internet, and due to her family's problems because of the pandemic. A modem represents a stressful part of Juanita's life as she was torn between being a student and a family member because of COVID-19. The boundaries of her emotions spread to other parts of her life and to her loved ones. How Juanita responded to these struggles reveals her motivation to continue her studies despite the hardship of leaving her home and family during Covid-19. Susana's choice of artifact also illustrates her emotional response to learning a language during the pandemic:

The coronavirus period has been pretty exhausting in many ways. In this context (FL class) I think it ruined my first experience with a teacher that I liked and that I was truly learning from. I only had two weeks of class so it's sad. However, that's not important if we see health as the main aspect... I thank God my family and I are fine and that we get to spend time together. I think I would save a small puzzle piece... I think that is a proof of patience and something that many families are doing (puzzles) during this period.

She mentions emotions such as "exhausting" and "sad" and describes feeling demotivated about her learning experience. Susana's use of "a small puzzle piece" is a metaphor revealing how she made sense of her experience during the coronavirus pandemic and what she gained from it: an understanding of the importance of health, patience, and her family. By focusing on a puzzle piece, Susana shows that although she may have felt demotivated, her experience outside of the virtual classroom encouraged her to gain perspective and thereby grow and mature during COVID- 19.

In addition to selecting artifacts that demonstrated their emotional roller-coaster, students also described how the pandemic affected their growth and development. As Rosa wrote, a stone illustrated how she changed as a person:

I think learning during this pandemic time is hard like stone, but I also think it has helped me to get sharper at being self-sufficient about my own learning. I have been able to think about my needs and adapt to the situation. This way, even if it is difficult, I'm getting sharper.

The phrase "hard like stone" shows her recognition that she developed into a more "self-sufficient" or autonomous student. Rosa felt motivated to become more attentive and flexible as a learner.

Other data similarly shows how students matured as they became more reflective, as Beto expressed here:

My experience during this pandemic was productive for me because it changed me. It provided me time 
to think and know what things are important and what things are not. I can relate this experience with the first wheel made by humans because this experience marked a change in my life. It made me a better person for myself, to focus on the important things in life and throw away the things that are not important. I am not the same person anymore.

He shows a deep level of thought regarding how he changed as a person. Beto associated his growth with the "first wheel made by humans," a simple invention that caused changes and advancement in society. Beto's experience during COVID-19 motived him to mature and grow as an individual.

From the data, one can observe how the students' challenges, both online and out-of-class, created emotional responses that affected their learning process. Unlike prior research that concentrated on emotions in the classroom or from the use of L2 (Arnold, 2011; Horwitz, 2016; Richards, 2015), the unique experience of a worldwide pandemic reveals the importance of "general" (MacIntyre \& Gardner, 1994) emotions in learning, no matter the source. Inspired by the impact of COvid-19, recent studies have identified a similar array of "general" emotions through questionnaires (Aristovnik et al., 2020; Karalis \& Raikou, 2020). While such studies present relevant results, they do not focus on emotions in learning or techniques for promoting student reflection. The guided journal technique used here shows how students overcame anxiety caused by Covid19 and were motivated to succeed as students. It reveals a level of reflection and recognition by the students of their growing autonomy, independence, and responsibility as learners. This is an unprecedented experience, and as it is ongoing, relevant literature is continuously developing. The drastic and sudden changes in education highlight the impact of emotions in language learning, and the intensity of emotions experienced during the time of COVID-19, as described here, contribute to our appreciation of emotions in the learning process.

\section{Discussion and Conclusion}

The data presented in this article reveals the obstacles confronted by BA in ELT students while studying a foreign language during the time of Covid-19 and the emotional responses those challenges evoked-anxiety largely overcome by motivation. It also demonstrates that through the use of guided journals, students were able to reach a deeper level of reflection and share their emotional growth in response to the trials they faced. Not only did the students meet their class requirements, but they also became more autonomous, independent, and responsible. Through their guided reflective journal entries, students discovered their own resilience in the time of COVID-19. The use of narrative in a guided journal prompt gave students a space to reflect on their experiences during the initial moments of the coronavirus pandemic from an imagined perspective in the future as survivors of covid-19, communicating anonymously with an unknown future historian. This task tapped into their imagination and creativity, encouraging a deeper reflection. As Vygotsky (1994) describes, revealing and understanding emotions as part of the learning process is relevant for all learners.

Our students' emotional responses to a social phenomenon were examined using Vygotskian sociocultural theory. Building on prior research about emotions and learning, we viewed student emotions in a previously unexplored learning environment: a worldwide pandemic. The results illustrate the importance of emotions in learning not only from the language classroom or L2 use (Arnold, 2011; Horwitz, 2016; MacIntyre \& Gardner, 1994; Richards, 2015), but from any source. For this research, a reflective technique within a facilitated space was created to explore emotions and learning. Guided reflective journals from an imagined perspective allowed us to see the array of emotions students experienced because of COVID-19 and appreciate the impact on their learning. This technique revealed how the participants made sense of what was happening 
to them and how this sense-making also influenced their relationships with technology, family, culture, and socio-economic issues. By fostering reflection, students were able to recognize and appreciate their own growth. Instead of being used to see "how the past is related to the present" (Coffey \& Atkinson, 1996, p. 68), the novel approach to narrative inquiry used here provided an understanding of the present through an imagined future perspective.

These results may be of interest to language teachers in other parts of the world, as well as to teacher educators, coordinators, and program designers. From this study, we recommend that language teachers foster student reflection about their emotions and language learning. Guided journals can create space for our students that encourages such reflection. Use of an imagined place and time sparks student creativity and provides a different perspective, yielding a new approach for student reflection. This unique way of journaling through narrative presents a means of uncovering and making sense by encouraging students to "stand back" (Moon, 2006) from an event. From this stance, students can appreciate their emotions at a deeper level and recognize their own growth. Creating a facilitated space for reflection makes student emotions visible for teachers as well as for the students themselves, leading to a better understanding of the learning process described by Vygotsky's term perezhivanie. Studying students' emotional responses to a social phenomenon such as COVID-19 not only helps explain the immediate emotional effects on their learning from that event, but also allows us to envision a future in which we may face other social phenomena and to recognize the importance of shedding light on emotions in the learning process more generally.

This study was limited by three factors. First, data collection might have included interviews or focus groups to allow additional insight. Second, although the timing of the study was favorable because it occurred at the beginning of COVID-19, students may have been hampered by time constraints as they were required to submit their journals before the semester ended. They may have reached a deeper level of reflection without that deadline. Third, this study did not include students without internet and access to computers or cellphones, and so does not represent their experiences or provide information about their emotions and learning during CoviD-19. In conclusion, coupling emotions with learning during a social phenomenon is relevant and warrants further research. This leaves open the potential for more exploration of emotions and learning for students in other contexts, as well as those without the resources necessary to take part in online classes.

\section{References}

Aristovnik, A., Keržic ${ }^{\vee}$, D., Ravšelj, D., Tomaževic ${ }^{\vee}$, N., \& Umek, L. (2020). Impacts of the Covid-19 pandemic on life of higher education students: A global perspective. Sustainability 2020, 12(8438), 1-34. https://doi.org/10.3390/su12208438

Arnold, J. (2009). Affect in L2 learning and teaching. Estudios de Lingüistica Inglesa Aplicada, 9, 145151. https://www.academia.edu/20103916/ Affect_in_L2_learning_and_teaching

Arnold, J. (2011). Attention to affect in language learning. Anglistik. International Journal of English Studies, 22(1),11-22.

Barkhuizen, G. (2019). Narrative knowledging in second language teaching and learning contexts. In A. De Fina \& A. Georgakopoulou (Eds.), The handbook of narrative analysis (pp. 97-116). Wiley Blackwell.

Barkhuizen, G., \& Wette, R. (2008). Narrative frames for investigating the experiences of language teachers. System, 36(3), 372-387.

Brown, H. D. (2014). Principles of language learning and teaching $\left(6^{\text {th }}\right.$ ed.). Pearson Education.

Burns, A. (2009). Action research in second language teacher education. In A. Burns \& J. C. Richards (Eds.), The Cambridge guide to second language teacher education (pp. 289-297). Cambridge University Press.

Carlyle, D., \& Woods, P. (2002). Emotions of teacher stress. Trentham.

Chakma, U., Li, B., \& Kabuhung, G. (2021). Creating online metacognitive spaces: Graduate research writing during the COVID-19 pandemic. Issues in Educational Research, 31(1),37-55. http://www.iier.org.au/iier31/chakma.pdf 
Clandinin, D. J., Steeves, P., \& Caine, V. (2013). Composing lives in transition: Early school leavers. Emerald Group Publishing Limited.

Coffey, A., \& Atkinson, P. (1996). Making sense of qualitative data: Complementary research strategies. Sage.

Denzin, N. K., \& Lincoln, Y. S. (2005). Introduction: The discipline and practice of qualitative research. In N. K. Denzin \& Y. S. Lincoln (Eds.), The Sage handbook of qualitative research ( $3^{\text {rd }}$ ed., pp. 1-44). Sage.

Dörnyei, Z. \& Chen, L. (2013). Motivation and vision: An analysis of future L2 self images, sensory styles, and imagery capacity across two target languages. Language Learning, 63(3), 437-462. https://doi. org/10.1111/lang.12005

Dörnyei, Z., \& Ushioda, E. (2011). Teaching and researching motivation. Pearson Education Limited.

Ellis, E. M. (2004). The invisible multilingual teacher: The contribution of language background to Australian ESL teachers' professional knowledge and beliefs. The International Journal of Multilingualism, 1(2), 90108.https://doi.org/10.1080/14790710408668181

Ellis, E. M. (2012). Language awareness and its relevance to TESOL. University of Sydney Papers in TESOL, 7 , 1-23. https://faculty.edfac.usyd.edu.au/projects/ usp_in_tesol/pdf/volume07/Article01.pdf

Farrell, T. S. C. (2013). Reflective practice in ESL teacher development groups: From practices to principles. Palgrave Macmillan.

Flowerdew, J. (1998). Language learning experience in L2 teacher education. TESOL Quarterly, 32(3), 529-535.

Forman, R. (2015). Becoming an L" learner (again): How a brief language learning experience sparked connections with SLA theory. Language Teaching Research, 19(1), 108-122. https://doi. org/10.1177/1362168814542721

Golombek, P., \& Doran, M. (2014). Unifying cognition, emotion, and activity in language teacher professional development. Teaching and Teacher Education, 39(2014), 102-111. http://www.personal. psu.edu/kej1/aplng587/Readings/Week_07_Cognition_Emotion/Golombek_Doran_2014.pdf

Golombek, P., \& Klager, P. (2019). Tracing teacher emerging conceptions in the moment through "tiny self talks". The European Journal of Applied Linguistics and TEFL, 8(2), 39-60.

Hargreaves, A. (1998). The emotional practice of teaching. Teaching and Teacher Education,
14(8), 835-854. https://doi.org/10.1016/ S0742-051X(98)00025-0

Holliday, A. (2007). Doing and writing qualitative research $\left(2^{\text {nd }}\right.$ ed.). Sage Publications.

Horwitz, E. K. (2016). Reflections on Horwitz (1986), Preliminary Evidence for the Validity and Reliability of a Foreign Language Anxiety Scale. TESOL Quarterly, 50(4), 932-935.

Karalis, T., \& Raikou, N. (2020). Teaching at the times of COVID-19: Inferences and implications for higher education pedagogy. International Journal of Academic Research in Business and Social Sciences, 10(5), 479-493. https://doi.org/10.6007/IJARBSS/ v10-i5/7219

Lengeling, M. M. (2010). Becoming an English teacher. Participants' voices and identities in an in/ service teacher training course in central Mexico. [libro electrónico en repositorio]. Universidad de Guanajuato, México. http://repositorio.ugto.mx/ handle/20.500.12059/1354

Lortie, D. C. (2002). Schoolteacher: A sociological study (2 $2^{\text {nd }}$ ed.). Chicago University Press.

MacIntyre, P. D., \& Gardner, R. C. (1994). The subtle effects of language anxiety on cognitive processing in the second language. Language Learning, 44, 283-305.

Masgoret, A. M., Gardner, R. C. (2003). Attitudes, motivation, and second language learning: A meta-analysis of studies conducted by Gardner and associates. Language Learning, 53(1), 167-210. https://doi. org/10.1111/1467-9922.00227

Mendez Lopez, M. G. (2020). Emotions attributions of ELT pre-service teachers and their effects on teaching experience. Profile, 22(1), 1-13. https://doi. org/10.15446/profile.v22n1.78613

McNiff, J. \& Whitehead, J. (2002). Action research: Principles and practice ( $2^{\text {nd }} \mathrm{ed}$.). RoutledgeFalmer.

Moon, J. A. (2006). Learning journals: A handbook for reflective practice and professional development $\left(2^{\text {nd }}\right.$ ed.). Routledge.

Noels, K. A. (2001). New orientations in language learning motivation: Towards a model of intrinsic, extrinsic, and integrative orientations and motivation. In $\mathrm{Z}$. Dörnyei \& R. Schmidt (Eds.), Motivation and second language learning (pp. 43-68). University of Hawai'i Press.

Pasaribu, T. A., \& Dewi, N. (2021). Indonesian EFL students' voices on online learning during COVID-19 through appraisal analysis. LEARN Journal, 14(1), 399-426. 
Prior, M. T. (2016). Emotion and discourse in L2 narrative research. Multilingual Matters.

Richards, J. C. (2015). Key issues in language teaching. Cambridge University Press.

Richards, K. A. R., \& Hemphill, M. A. (2018). A practical guide to collaborative qualitative data analysis. Journal of Teaching in Physical Education, 37(2), 225-231. https://doi.org/10.1123/jtpe.2017-0084

Song, J. (2016). Emotions and language teacher identity: Conflicts, vulnerability, and transformation. TESOL Quarterly, 50(3), 631-654. https://doi. org/10.1002/tesq.312

Scovel, T. (2001). Learning new languages: A guide to second language acquisition. Heinle.

Squire, C., Andrews, M., \& Tamboukou, M. (2013). Introduction: What is narrative research? In M. Andrews, C. Squire, \& M. Tamboukou (Eds.), Doing narrative research ( $2^{\text {nd }}$ ed., pp. 1-26). Sage Publications Ltd.

Squire, C., Davis, M., Esin, C., Andrews, M., Harrison, B., Hydén, L-C, \& Hydén, M. (2014). What is narrative research? Bloomsbury.
Strauss, V. (2020, April 17). A history professor gave students an unusual assignment. Here are the results. Washington Post. https://www.washingtonpost.com/education/2020/04/17/ history-professor-gave-students-an-unusual-assignment-here-are-results/

Vygotsky, L. S. (1981). The genesis of higher mental functions. In J. V. Wertsch (Ed.), The concept of activity in Soviet psychology (pp. 144-188). Sharpe.

Vygotsky, L. S. (1994). The problem of the environment. In R. van der Veer \& J. Valsiner (Eds.), The Vygotsky reader (pp. 338-354). Blackwell Publishers.

Wilson, A. K. (2017). A narrator of stories shares his own: An interview with Gary Barkhuizen. MEXTESOL Journal, 41(1), 1-7. http://www.mextesol.net/journal/index.php?page $=$ journal\&id_article $=1871$

Zembylas, M. (2003). Emotions and teacher identity: A poststructural perspective. Teachers and Teaching, 9(3), 213-238. https://doi. org/10.1080/13540600309378

How to cite this article: Wilson, A. K., \& Lengeling, M. M. (2021). Language learning in the time of COVID-19: ELT students' narrated experiences in guided reflective journals. Íkala, Revista de Lenguajey Cultura, 26(3), 571-585. https://doi.org/10.17533/udea.ikala.v26n3a06 
